\title{
An approach to the intelligent drug delivery systems: Thermo-responsive membrane for pulsatile drug delivery
}

\author{
Evren Atlihan Gündoğdu, Levent Kırılmaz
}

\begin{abstract}
In this study, the potential use of thermotropic liquid crystals as a responsive release system was investigated. Cholesteryl oleyl carbonate liquid crystal (COC) has been embedded in nylon membranes by using vacuum filtration methods. In vitro drug release studies were performed by using a fluid/fluid diffusion cell. Sodium salicylate as a model drug penetration study was performed in nylon membrane with or without COC that is prepared at 25 and $37^{\circ} \mathrm{C}$. Also the penetration studies were performed by repeatedly exchanging the temperature cycle $\left(10,25,37^{\circ} \mathrm{C}\right)$ of the water bath at predetermined intervals. It was observed that $\mathrm{COC}$ and temperature have effects on the penetration of sodium salicylate. At $37^{\circ} \mathrm{C}$, the penetration rate of sodium salicylate was found higher than $25^{\circ} \mathrm{C}$ and $10^{\circ} \mathrm{C}$, respectively. Also, the penetration amount of sodium salicylate has changed as pulsatile drug delivery in the presence of COC. As a result, according to the patients' requirements, it seems that the penetration rate and profile can be adjusted by developing pulsatile drug delivery as a new system.
\end{abstract}

KEYWORDS: Cholesteryl oleyl carbonate, nylon membrane, pulsatile drug delivery, sodium salicylate

\section{INTRODUCTION}

Transdermal delivery has recently become an important means of drug administration. Although many transdermal therapeutic systems have been fabricated with the different mechanism to sustain the release of drugs, none of these systems are able to control the drug release according to the requirement of the patients or a preprogrammed schedule (1-3).

To design an intelligent drug delivery system, not only acts as a rate-controlling system but also delivers the drug when it is required, seems attractive and effective method to prevent the occurrence of tolerance and achieved by delivering drug efficiently to the right place with the right amount of drug at the right time. In order to achieve this goal, choronotherapy has been recently taken into account in clinical therapy for getting a maximum therapeutic effect of drug and mini- mum side effects $(4,5)$. According to the concept of chronopharmacology, drug released from different dosage forms should be preferably delivered by a pulsatile fashion according to the physiological needs rather than a continuous delivery $(6,7)$.

Liquid crystal embedded membranes are used because of their biocompatibility for transdermal drug delivery. Biological membranes are capable of reversible structural modification in a liquid crystalline state, and their permeation and selectivity are closely associated with the gel-liquid crystal phase transition (8). Similarly, liquid crystal in polymer membranes might be applicable to modulate the permeability. Cholesteric liquid crystals have been successfully embedded in various membranes to thermally control the permeation (9-11). Cholesteryl oleyl carbonate (COC) embedded membranes are expected more sensitive to minute temperature changes (12). Phase
AFFILIATIONS

Department of

Biopharmaceutics and

Pharmacokinetics, Ege

University, Faculty of

Pharmacy, Izmir, Turkey

CORRESPONDENCE

E. Atlihan Gundogdu

E-mail:

evren.gundogdu@ege.edu.tr

Received:

11.04.2013

Revision:

20.05.2013

Accepted:

28.05.2013 
transition temperature of $\mathrm{COC}$ was near $18{ }^{\circ} \mathrm{C}$ for a reversible simectic-cholesteric transition. For the medical use of COC, the phase transition temperature has to be higher than skin temperature (13). The aim of this study was to investigate the usage of thermo-switchable COC-embedded membrane in controlling drug penetration and thermo physical property of liquid crystal. The thermo-responsive effect was examined by in vitro penetration study by a step-wise change in temperature cycle. For this purpose, analgesic agent, sodium salicylate was used as a model drug (14).

\section{MATERIALS AND METHODS Material}

COC was purchased from Sigma Chem. Co. and used without further purification. Nylon membranes (pore size $0.45 \mathrm{~mm} ; 4$ $\mathrm{mm}$ ) were obtained from Whatman Limited (England). Sodium salicylate was used as a model drug and supplied from Mustafa Nevzat Drug Company (Turkey). All the other reagents and chemicals were reagent grade.

\section{FT-IR spectroscopy study}

A small amount of COC was sealed into potassium bromure pellet by a hydraulic press $\left(200 \mathrm{~kg} / \mathrm{cm}^{2}, 15 \mathrm{~s}\right)$. This pellet sample was directly inserted into the cell. The cell was then placed on the FTIR spectrometer (Perkin Elmer Spectrum 100) and the procedure was carried out with time- scan measurement program.

\section{Differential scanning calorimeter}

Differential scanning calorimeter (DSC-910) was used to determine the thermal properties of the samples. The heating rate was $3^{\circ} \mathrm{C} / \min$ from 10 to $100{ }^{\circ} \mathrm{C}$, with an open pan system under stream of a nitrogen gas flow.

\section{Preparation of COC-embedded nylon membranes}

COC-embedded membranes were prepared via vacuum filtration (KNF Neuberger, 4 bar) at $25^{\circ} \mathrm{C}$ and $37^{\circ} \mathrm{C}$. Membranes were mounted individually on the glass filter holder (Sartorius). $0.25 \%$ COC solution in chloroform was filtrated using reducing pressure. The membranes were then dried at 25 and 37 ${ }^{\circ} \mathrm{C}$ for $24 \mathrm{~h}$. The COC-embedded nylon membranes were evaluated by gravimetrically before and after manufacturing.

\section{In vitro penetration studies}

In vitro drug penetration was studied using a fluid/fluid diffusion cell. The COC-embedded and without COC-membranes were carefully mounted in a two-chamber diffusion cell having an available diffusion area of $3.14 \mathrm{~cm}^{2} .0 .25 \%$ aqueous solution of sodium salicylate was put into the donor cell and the receptor chamber was filled only with the same volume $(50 \mathrm{~mL}$ of each volume) of distilled water. The penetration studies were carried out at $10{ }^{\circ} \mathrm{C}, 25^{\circ} \mathrm{C}$ and $37 \mathrm{oC}$ by exchanging the temperature cycle. The amount of sodium salicylate penetrated was assayed spectrophotometrically at $296 \mathrm{~nm}$ (Shimadzu UV-1208). The penetration rates were calculated from the slope of curves at each period. These studies were performed triplicate.

\section{RESULTS AND DISCUSSION}

Spectra and Thermotropic Behavior of cholesteryl oleyl carbonate COC used in this study shows phase transition due to temperature. It was found that transition temperature of COC from smectic phase to cholesteric phase is approximate-

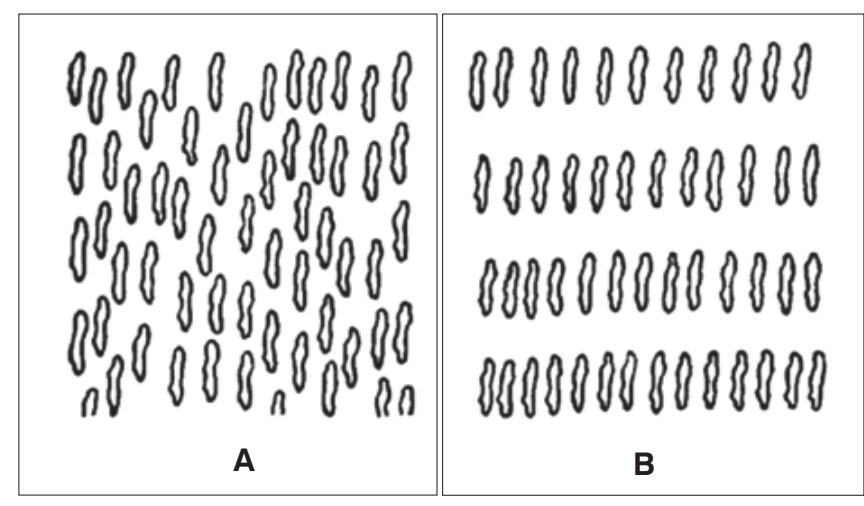

FIGURE 1. The phase of liquid crystals. The chiral nematic phase (left), also called the cholesteric phase, and the smectic $\mathrm{C}$ phase (right).

ly $20^{\circ} \mathrm{C}$ and from cholesteric phase to isotropic phase is approximately $40^{\circ} \mathrm{C}$.

Figure 1 shows the DSC thermograms of COC. It clearly indicates that endothermic peak was obviously observed from DSC curves of COC. The endothermic peak at $37.23{ }^{\circ} \mathrm{C}$ corresponded to the cholesteric-isotropic transition of pure COC.

The temperature dependence of FT- IR spectra of COC is displayed Figure 2. The peaks ranging from 3000 to $2850 \mathrm{~cm}^{-1}$ are attributed to the symmetric and asymmetric $\mathrm{CH}$ stretching vibration. The peak at $1742.43 \mathrm{~cm}^{-1}$ is assigned to the carbonyl stretching of ester. The peaks at 1466.49 and $1383.99 \mathrm{~cm}^{-1}$ are due to the $\mathrm{CH}_{2}$ and $\mathrm{CH}_{3}$ bending vibrations. The peaks around $1265-1252 \mathrm{~cm}^{-1}$ originate from COC.

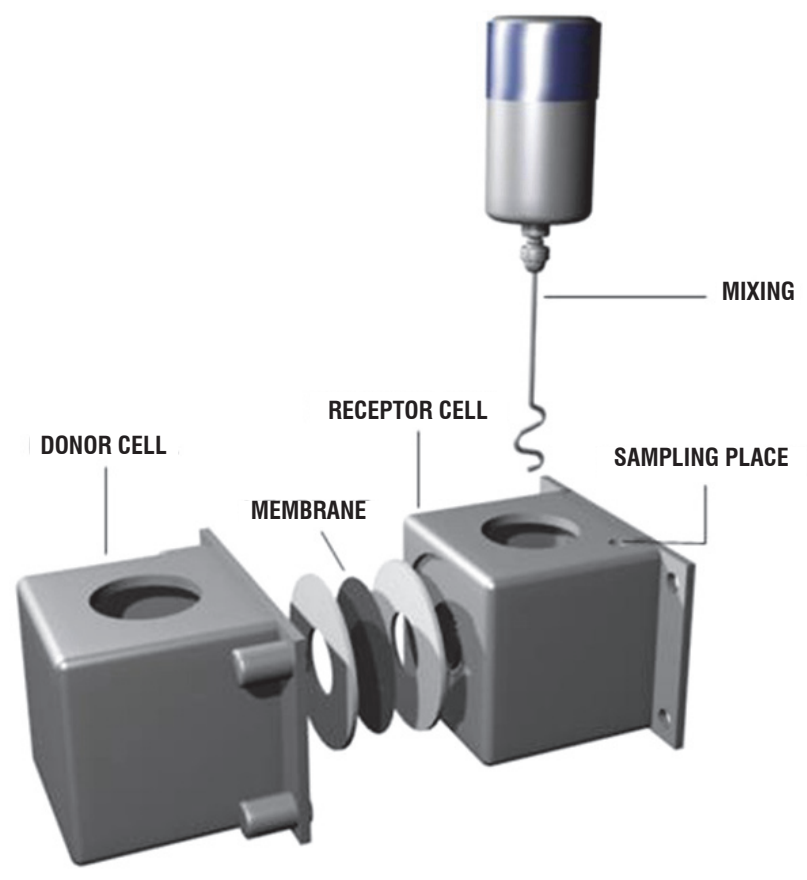

FIGURE 2. The schematic representation of fluid/fluid diffusion cell.

Preparation of COC-embedded nylon membrane

The absorbed COC amounts are found $0.0557 \mathrm{mg} / \mathrm{cm}^{2}$ and $0.0288 \mathrm{mg} / \mathrm{cm}^{2}$ for the membranes manufactured at 25 and 37 ${ }^{\circ} \mathrm{C}$, respectively. 


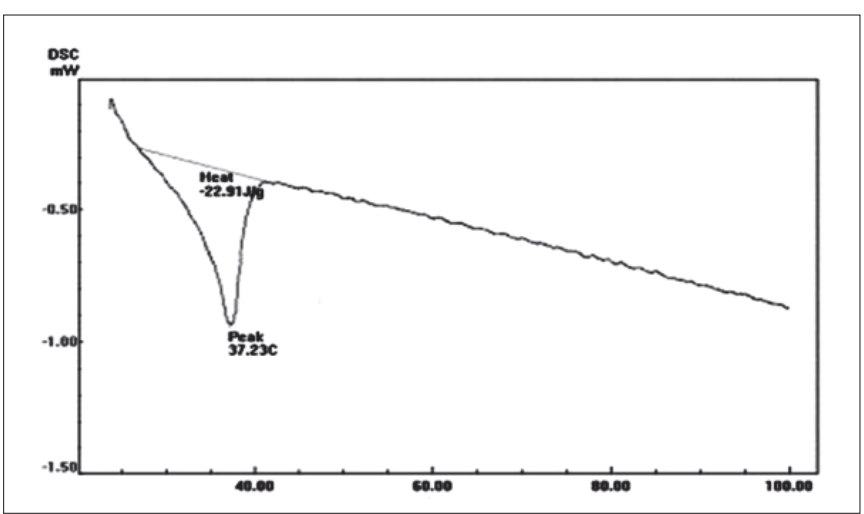

FIGURE 3. DSC thermograms of COC.

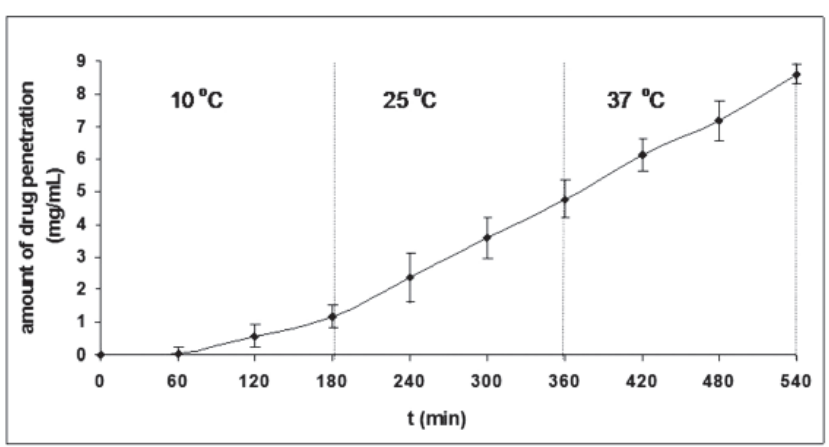

FIGURE 5. The penetration of Sodium Salicylate through cellulose nitrate membrane without COC

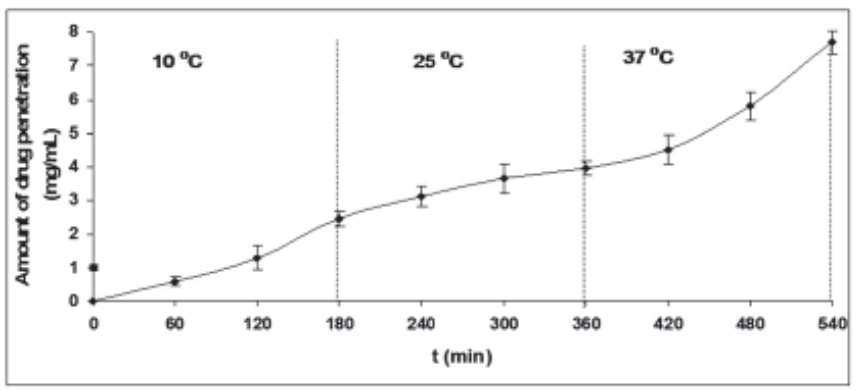

FIGURE 7. The penetration of Sodium Salicylate through cellulose nitrate membrane with COC

\section{Penetration Studies through Nylon Membrane without Cholesteryl Oleyl Carbonate}

The penetration profiles of sodium salicylate through these membranes that stored 25 and $37^{\circ} \mathrm{C}$ in responsive to temperatures are shown in Figure 3 and 4. In order to evaluate whether membranes without COC have thermo-responsive function, the permeation study was performed by a system with temperature cycling between $10^{\circ} \mathrm{C}$ and $37^{\circ} \mathrm{C}$. It is clearly seen that there is not any thermo-responsive function. The penetration rate of sodium salicylate through the membrane without COC only increased approximately 0.6 -fold from $10^{\circ} \mathrm{C}$ to $25^{\circ} \mathrm{C}$ and approximately 0,8 -fold from $25^{\circ} \mathrm{C}$ to $37^{\circ} \mathrm{C}$.

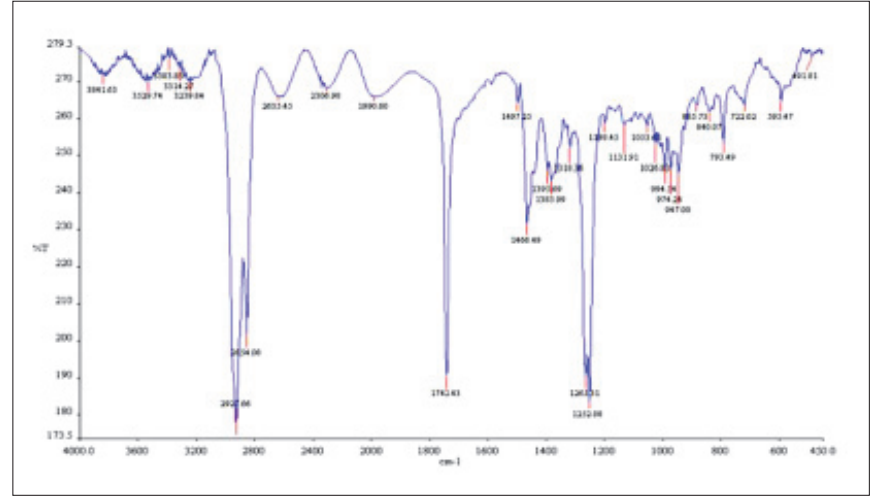

FIGURE 4. $\mathrm{FT}-\mathrm{IR}$ spectra of $\mathrm{COC}$ at $37^{\circ} \mathrm{C}$

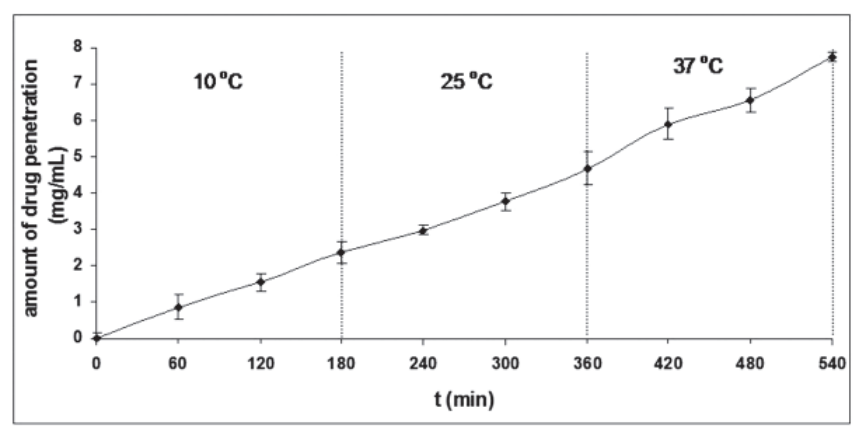

FIGURE 6. The penetration of Sodium Salicylate through nylon membrane without $\mathrm{COC}$

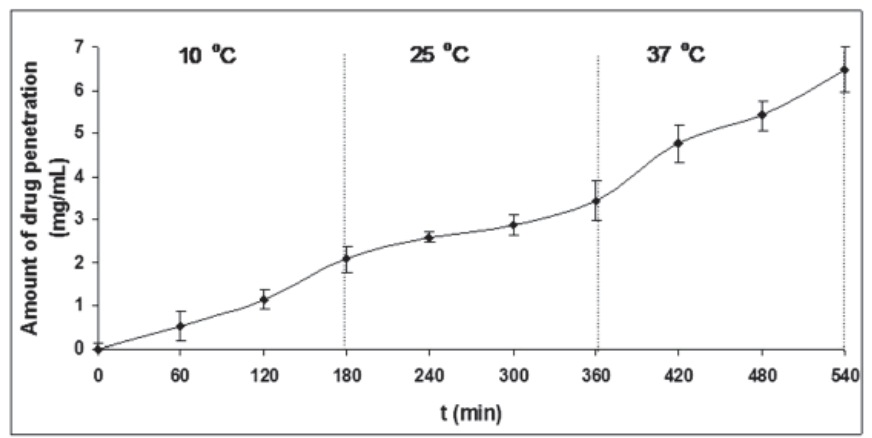

FIGURE 8. The penetration of Sodium Salicylate through nylon membrane with COC.

\section{Penetration Studies of Drug through Cholesteryl Oleyl Carbonate-Embedded Nylon Membrane}

The penetration profiles obtained from COC-embedded membranes are shown in Figure 5 and Figure 6. Furthermore, the penetration rates are given in Table 1 . It was seen that COC played an important role in controlling sodium salicylate penetration and a thermo-responsive function was observed. When the COC-embedded membrane was prepared and stored at $37^{\circ} \mathrm{C}$, the penetration rate of sodium salicylate was less than prepared at $25^{\circ} \mathrm{C}$.

\section{CONCLUSION}

In order to evaluate the thermo-responsive efficacy of the COC embedded nylon membrane, the penetration study was 
TABLE 1. Penetration rate values $\left(\mathrm{mg} / \mathrm{cm}^{2}\right.$.h) for nylon and cellulose nitrate membrane without COC (The penetration rates were not different statistically for each temperature, $p>0.05$ )

\begin{tabular}{ccc}
\hline Temperature $\left({ }^{\circ} \mathbf{C}\right)$ & I & II \\
\hline 10 & $0,0195 \pm 0,003$ & $0,0135 \pm 0,0018$ \\
25 & $0,0200 \pm 0,0022$ & $0,0141 \pm 0,0009$ \\
37 & $0,0206 \pm 0,0018$ & $0,0152 \pm 0,0012$
\end{tabular}

I: The penetration rate of Sodium Salicylate through cellulose nitrate membrane without $\mathrm{COC}$ II: The penetration rate of Sodium Salicylate through nylon membrane without COC
TABLE 2. Penetration rate values $\left(\mathrm{mg} / \mathrm{cm}^{2}\right.$.h) for nylon and cellulose nitrate membrane with COC (The penetration rates were different statistically for 25 and $37^{\circ} \mathrm{C}, 10$ and $\left.37^{\circ} \mathrm{C}, \mathrm{p}<0.05\right)$

\begin{tabular}{ccc}
\hline Temperature & I & II \\
\hline 10 & $0,0155 \pm 0,0044$ & $0,00592 \pm 0,0014$ \\
25 & $0,0170 \pm 0,0023$ & $0,00690 \pm 0,0013$ \\
37 & $0,0264 \pm 0,0038$ & $0,01427 \pm 0,0021$ \\
\hline I: The penetration rate of Sodium Salicylate through cellulose nitrate membrane with COC \\
II: The penetration rate of Sodium Salicylate through nylon membrane with COC
\end{tabular}

performed in vitro by a system with step wise change in temperature cycle between $10-25-37^{\circ} \mathrm{C}$. When the drug penetration study was carried out at $10{ }^{\circ} \mathrm{C}$, the penetration was too low. If the temperature was changed from $10^{\circ} \mathrm{C}$ to $25^{\circ} \mathrm{C}$, the penetration of drug increased; but when the temperature was changed from $25{ }^{\circ} \mathrm{C}$ to $37^{\circ} \mathrm{C}$, the penetration of drug increased remarkably. This increase in penetration was because of activation of thermal molecular motion of liquid crystal in the membrane.

When the COC absorbed membranes were stored at $37^{\circ} \mathrm{C}$, the amount of drug penetrating through this membrane was the lowest, as compared with stored at $25^{\circ} \mathrm{C}$. The change of phase transitional temperature might be responsible for this result. Moreover, the higher activation of molecular motion of COC on the membranes during storage at higher temperature made it easy to entrap COC into the pore of membrane and to delay the penetration of drug.
The penetration of sodium salicylate through nylon membrane without COC was higher than with COC membrane but COCembedded membranes obtained the controlled release for sodium salicylate. When the results compared to statistically, the COC embedded membrane and without COC membrane results found different.

The temperature is below the phase transition temperature the liquid crystals are disaggregated and almost spread on the membrane. But when the temperature is higher than the phase transition temperature the liquid crystals aggregate to the nylon membrane to create channels for drug penetration (10). This reversible property of liquid crystal caused a reversible regulation in the penetration rate of sodium salicylate in response to the temperature change.

In conclusion, COC-embedded nylon membrane can be developed to obtain a thermo-responsive membrane and pulsatile drug release. The manufacturing and storage temperatures have an important role on the penetration of sodium salicylate.

\section{Akıllı ilaç taşıma sistemlerine yeni yaklaşımlar: ısıya duyarlı membranlar}

ÖZET: Bu çalışmada termotropik katı kristallerin uyarıcı salım sistemleri olarak potansiyel kullanımı araştırılmıştır. Kolesteril oleil karbonat vakum filtrasyon yöntemiyle naylon membranlara emdirilmiştir. İn vitro ilaç penetrasyon çaIışmaları sıvı/sıvı difüzyon hücresi kullanılarak yapılmıştır. Model ilaç olarak kullanılan sodyum salisilatın kolesteril oleil karbonat içeren ve içermeyen naylon membranlardan penetrasyon çalışmaları belirli zaman aralıklarında, 10, 25 ve $37^{\circ} \mathrm{C}$ sıcaklık değişim döngüsü sağlanan su banyosunda yapılmıştır. Elde edilen veriler, kolesteril oleil karbonatın ve sıcaklığın sodyum salisilatın penetrasyonu üzerine etkileri olduğunu göstermiştir. $37^{\circ} \mathrm{C}$ 'de sodyum salisilatın penetrasyon hızı sırayla 25 ve $10^{\circ}$ C'ye göre daha yüksek bulunmuştur. Ayrıca sodyum salisilatın penetrasyon hızı kolesteril oleil karbonat varlığında pulsatil (basamaklı) ilaç uygulaması gibi değişim göstermiştir. Sonuç olarak, hasta ihtiyacına göre, ilaç penetrasyon hızı yeni sistemler olan pulsatil ilaç uygulamalarının geliştirilmesiyle ayarlanabilir.

ANAHTAR KELIMELER: Kolesteril oleil karbonat, naylon membran, pulsatil ilaç uygulamaları, sodyum salisilat 


\section{REFERENCES}

1. Lin $Y Y$, Chen KS, Lin SY. Development and investigation of a thermo- responsive cholesteryl oleyl carbonateembedded membrane. J Control Rel 1996; 41: 163-70.

2. Lin YY, Chen KS, Lin SY. Temperature effect on the thermal characteristics and drug penetrability of the thermally on-off switching membrane. Int J Pharm 1995; 124: 53-9.

3. Atlihan E. Kolesteril oleil karbonat likit kristalinin kontrollü salım sistemlerinde kullanımının in vitro olarak araştırılması. Ege Üniversitesi Sağlık Bilimleri Enstitüsü, Yüksek Lisans Tezi, İzmir. 2004.

4. Lin SY, Lin YY, Chen KS. Permeation behavior of salbutamol sulphate through hydrophilic and hydrophobic membranes embedded by thermo-responsive cholesteryl oleyl carbonate. Pharmaceut Res 1996; 13: 914-9.

5. Lin YY, Chen KS, Lin SY. Thermophysical properties of cholesteryl oleyl carbonate determined with microscopic FTIR/DSC system. J Chin Chem Soc 1995; 42: 865-8.

6. $D^{\prime}$ Emanuele A. Responsive polymeric drug delivery systems. Clin Pharmacokinet 1996; 31: 241-5.

7. Watson SJ, D'Emanuele A, Gleeson HF. Liquid crystal embedded membranes for use in responsive release delivery systems. AAPS-Assoc. of American Pharmacists' Symposium Book, San Francisco. 1998.
8. Lin SY, Lin HL, Li MJ. Reproducibility of temperature response and long-term stability of thermo-responsive membrane prepared by adsorption of binary liquid crystals. J Membr Sci 2003; 225: 135-43.

9. Lin SY, Chen KS, Lin YY. Ph of preparations affecting the on-off drug penetration behavior through the thermo-responsive liquid crystal embedded-membrane. J Control Rel 1998; 55: 13-20.

10. Lin SY, Ho CJ, Li MJ. Precision and reproducibility of temperature response of a thermo-responsive membrane embedded by binary liquid crystals for drug delivery. J Control Rel 2001; 73: 293-301.

11. Lin SY, Lin HL, Li MJ. Manufacturing affecting the drug delivery function of thermo-responsive membrane prepared by adsorption of binary liquid crystals. Eur J Pharm Sci 2002; 17: 153-60.

12. Lin SY, Lin HL, Li MJ. Adsorption of binary liquid crystals on to cellulose membrane for thermo-responsive drug delivery. J Int Adsorp Soc 2002; 8: 197-202.

13. Lin SY, Tseng HY, Li MJ. Phase studies and thermal stability of binary systems of cholesteric liquid crystals. Appl Phys A 2000; 70: 663-8.

14. Lin SY, Lin YY, Chen KS. A thermo-switchable membrane for drug delivery. Drug Deliv 1995; 2: 123-7. 